\title{
Staphylococcus aureus growth delay after exposure to low fluencies of blue light $(470 \mathrm{~nm})$
}

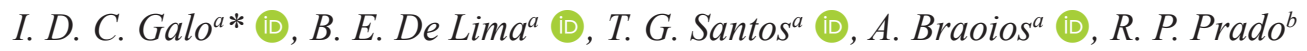 \\ and W. G. Dos Santos ${ }^{a}$
}

aUnidade Acadêmica Especial de Ciências da Saúde, Programa de Pós-graduação em Ciências Aplicadas à Saúde, Universidade Federal de Goiás - UFG, Regional Jataí, Câmpus Jatobá, Cidade Universitária, BR 364, Km 195, 3800 , CEP 75801-615, Jataí, GO, Brasil

bDepartamento de Medicina, Universidade Federal de Goiás - UFG, Regional Catalão, Campus II, Av. Castelo Branco, s/n, Setor Universitário, CEP 75704-020, Catalão, GO, Brasil

*e-mail: idcgalo@gmail.com

Received: July 23, 2019 - Accepted: November 9, 2019 - Distributed: May 31, 2021

(With 2 figures)

\begin{abstract}
Antibiotic resistance is one of the greatest challenges to treat bacterial infections worldwide, leading to increase in medical expenses, prolonged hospital stay and increased mortality. The use of blue light has been suggested as an innovative alternative to overcome this problem. In this study we analyzed the antibacterial effect of blue light using low emission parameters on Staphylococcus aureus cultures. In vitro bacterial cultures were used in two experimental approaches. The first approach included single or fractionated blue light application provided by LED emitters (470 $\mathrm{nm})$, with the following fluencies: $16.29,27.16$ and $54.32 \mathrm{~J} / \mathrm{cm}^{2}$. For the second approach a power LED (470 $\left.\mathrm{nm}\right)$ was used to deliver $54.32 \mathrm{~J} / \mathrm{cm}^{2}$ fractionated in 3 applications. Our results demonstrated that bacterial cultures exposed to fractionated blue light radiation exhibited significantly smaller sizes colonies than the control group after $24 \mathrm{~h}$ incubation, however the affected bacteria were able to adapt and continue to proliferate after prolonged incubation time. We could conclude that the hypothetical clinical use of low fluencies of blue light as an antibacterial treatment is risky, since its action is not definitive and proves to be ineffective at least for the strain used in this study.
\end{abstract}

Keywords: blue light, photobiomodulation, Staphylococcus aureus, in vitro study.

\section{Atraso no crescimento de Staphylococcus aureus após exposição à baixas fluências de luz azul (470 nm)}

\begin{abstract}
Resumo
A resistência a antibióticos é um dos maiores desafios para o tratamento de infecções bacterianas em todo o mundo, levando ao aumento de despesas médicas, prolongamento da internação hospitalar e aumento da mortalidade. O uso da luz azul tem sido sugerido como uma alternativa inovadora para superar esse problema. Neste estudo, analisamos o efeito antibacteriano da luz azul usando parâmetros de baixa emissão em culturas de Staphylococcus aureus. Culturas bacterianas foram usadas em duas abordagens experimentais in vitro. A primeira abordagem incluiu o uso da aplicação única ou fracionada de luz azul fornecida por emissores de LED (470 nm), com as seguintes fluências: $16,29,27,16$ e $54,32 \mathrm{~J} / \mathrm{cm}^{2}$. Para a segunda abordagem, um LED de potência (470 nm) foi usado para fornecer $54,32 \mathrm{~J} / \mathrm{cm}^{2}$ fracionado em 3 aplicações. Nossos resultados demonstraram que as culturas bacterianas expostas à radiação de luz azul fracionada exibiram colônias de tamanhos significativamente menores do que o grupo controle após 24 h de incubação, no entanto, as bactérias afetadas foram capazes de se adaptar e continuar a proliferar após um tempo prolongado de incubação. Podemos concluir que o uso clínico hipotético de baixas fluências de luz azul como tratamento antibacteriano é arriscado, pois sua ação não é definitiva e mostra-se ineficaz, pelo menos para a cepa utilizada neste estudo.
\end{abstract}

Palavras-chave: luz azul, fotobiomodulação, Staphylococcus aureus, estudo in vitro.

\section{Introduction}

It has been demonstrated that several bacterial species are able to develop resistance to pharmacological treatment due to inappropriate and longstanding use of antibiotic drugs
(Dai et al., 2012; Bumah et al., 2013; Meurer et al., 2019; Rupel et al., 2019). Staphylococcus aureus (S. aureus) is a Gram-positive aerobic bacterium, which presents a highly 
evolved capacity of developing resistance to antimicrobial drugs. Additionally, it is an important etiological agent in skin wound contaminations, often evolving to generalized infections (Enwemeka et al., 2009; Bumah et al., 2013, 2015; Sousa et al., 2015; Freitas et al., 2018; Ferrer-Espada et al., 2019; Rupel et al., 2019).

Bacterial resistance and reproduction speed make it difficult to deal with infections caused by bacterial microorganisms and this fact leads to increased mortality risk to the patient as well as increased treatment cost and prolonged hospital stay. Therefore, there is an urgent need for safe, efficient and cheap therapeutic alternatives to combat bacterial agents like $S$. aureus (Enwemeka et al., 2009; Bumah et al., 2015; Rupel et al., 2019).

Photobiomodulation using wavelength between violet and blue spectrum (405-470 $\mathrm{nm}$ ) has been receiving great attention in the last decade and is considered an example of antibacterial therapy. Thus, the effect of blue light on different species of bacteria has been the subject of several studies (Feuerstein, 2012; Bumah et al., 2013; Dai et al., 2013; Guffey et al., 2013; Sousa et al., 2015; Wang et al., 2017, Ferrer-Espada et al., 2019; Meurer et al., 2019; Rupel et al., 2019; Schmid et al., 2019). The blue light antimicrobial effect has been observed using different experiment protocols, however, the true mechanism of action is still not fully understood (Chui et al., 2012; Dai et al., 2013; Bumah et al., 2015; Wang et al., 2017; Rupel et al., 2019; Schmid et al., 2019). Furthermore, the optimal emission parameter values to be used, especially regarding irradiance and fluence, are currently in discussion among several researchers. However, there is controversy over the use of low blue light emission parameters as a topical antimicrobial therapy (Chui et al., 2012; Bumah et al., 2015; Sousa et al., 2015; Meurer et al., 2019; Schmid et al., 2019).

Thus, considering all the conflicting data reported in the literature the aim of this study was to verify the in vitro effect of blue light $(470 \mathrm{~nm})$ in $S$. aureus bacterial cultures by using low irradiance and fluence values at single and fractionated applications.

\section{Material and Methods}

\subsection{Bacterial strain and cultures}

S. aureus strain (ATCC 25923) was obtained from the American Type Culture Collection cultures. For the Experiment 1, the bacterium was inoculated in sterile saline solution, in order to obtain a scale of $0.5 \mathrm{McF}$ arland turbidity standard $\left(1.5 \times 10^{8} \mathrm{CFU} / \mathrm{mL}\right)$ and the streak was made using a sterile swab all over the surface of a $150 \mathrm{~mm}$ diameter sterile Petri dishes containing Mueller-Hinton agar. For the Experiment 2, serial dilution (1:10000) was made from the same scale as mentioned before, $100 \mu \mathrm{L}$ of the diluted solution was pipetted into $55 \mathrm{~mm}$ diameter Petri dishes containing Mueller-Hinton agar and the streak was made using a Drigalski spatula.

\subsection{Light emitters}

A blue Light-Emitting Diode (LED), with a viewing angle of $30^{\circ}$, emitting a continuous beam of $470 \mathrm{~nm}$ wavelength, $0.247 \mathrm{~cm}^{2}$ beam area, $4.92 \mathrm{~mW}$ radiometric power, and irradiance of $19.92 \mathrm{~mW} / \mathrm{cm}^{2}$ was used to irradiate each exposure area in Experiment 1. The LED was positioned at a distance of $2.13 \mathrm{~cm}$, perpendicularly, from the bacterial culture surface. The exposure times adopted were $13.63,22.72$ and $45.45 \mathrm{~min}$, respectively generating the following low fluencies: $16.29,27.16$ and $54.32 \mathrm{~J} / \mathrm{cm}^{2}$.

In Experiment 2, a power LED (470 nm, continuous beam, $120^{\circ}$ viewing angle, $850 \mathrm{~mW}$ radiometric power, $35.22 \mathrm{~mW} / \mathrm{cm}^{2}$ irradiance) was used. It was positioned at a distance of $4.8 \mathrm{~cm}$, perpendicularly, from the bacterial culture surface, which generated a beam area of $24.13 \mathrm{~cm}^{2}$ and allowed to cover the entire surface of the dish. The fluence used was $54.32 \mathrm{~J} / \mathrm{cm}^{2}$, which was fractionated in 3 applications of $18.106 \mathrm{~J} / \mathrm{cm}^{2}$. The exposure time of each application was $8.56 \mathrm{~min}$ (25.7 $\mathrm{min}$ total).

In both experiments, the temperature of the surface irradiated by the light was monitored, always remaining below $30^{\circ} \mathrm{C}$, insufficient to generate any changes of the culture medium.

\subsection{Experimental protocols}

Experiment 1 was divided in Protocol 1 and Protocol 2. For both protocols, each exposure area was labelled with a dot (3 dots per dish). Each LED was positioned over a specific marked dot so that adequate fluence was applied to each one.

The Protocol 1 consisted of applying each fluence $\left(16.29,27.26\right.$ and $\left.54.32 \mathrm{~J} / \mathrm{cm}^{2}\right)$ in each exposure area at a single time. Eight dishes were used: Experimental Group $1(\mathrm{n}=4)$ and Control Group $1(\mathrm{n}=4)$. Both experimental and control dishes were incubated for 24 hours at $36.5^{\circ} \mathrm{C}$ after the light exposure.

The Protocol 2 consisted of fractionating each fluence in three exposures, obtaining the following fractionated fluencies: $5.43,9.053$ and $18.106 \mathrm{~J} / \mathrm{cm}^{2}$, each one was used at a specific area. Eight dishes were used: Experimental Group $2(n=4)$ and Control Group $2(n=4)$. Between each of the three exposures, it was allowed a 10-minute pause. Both experimental and control dishes were incubated for 24 hours at $36.5^{\circ} \mathrm{C}$ after the final light exposure.

In Experiment 2, twelve dishes were used: Experimental Group $3(n=6)$ and Control Group $3(n=6)$. A 1:10000 dilution from the $0.5 \mathrm{McF}$ arland scale was obtained and seeded onto the dishes. For the experimental group, there was a fractional application of the fluence of $54.32 \mathrm{~J} / \mathrm{cm}^{2}$ of the blue light (three exposures with a 10 -minutes pause between each one).

Control dishes were always positioned side by side with experimental dishes from the same protocol, so that the environment influence was the same on them, but not being exposed to the light from the other dish.

At the end, digital photos of all dishes were taken after 24 and 48 hours of incubation. For Experiment 1, a comparison between experimental and control groups was established 
and the main goal was to verify the existence of inhibition halos on areas exposed to blue light. For Experiment 2, the photos were used for counting colonies and for measuring colony diameters using ImageJ software.

\subsection{Statistical analysis}

The statistical analyses were done using SPSS 17.0 software. The normality of the sample distribution was confirmed by the Shapiro-Wilk test. Data were expressed as mean \pm standard deviation and Student's t-test for independent samples $(\mathrm{p}<0.05)$ was used to compare experimental and control groups.

\section{Results}

Considering the seeding pattern and the incubated temperature, the bacterial growth was as expected in all of the control dishes of Experiment 1 (see Figure 1A). There were no inhibition areas on Experimental Group 1 dishes, revealing that single applications of low blue light fluencies do not induce growth inhibition in $S$. aureus cultures.

On the other hand, on Experimental Group 2 dishes, there were discreet inhibition areas at the application dots previously labelled (see Figure 1B). The verified inhibition pattern suggests a fluence-dependent of the blue light antibacterial action, with $54.32 \mathrm{~J} / \mathrm{cm}^{2}$ the most effective fluence.

In Experiment 2, a dilution was performed in order to obtain isolated colonies, as seen in Figure 2. The mean number of colonies for Experimental Group 3 was $127.16 \pm 24.50$, and the mean for Control Group 3 was $132.33 \pm 13.80$. There was no statistically significant difference between these counts $(\mathrm{p}=0.706)$, indicating that the fractionated fluence of $54.32 \mathrm{~J} / \mathrm{cm}^{2}$ was not enough to suppress the proliferation of $S$. aureus from lower density inoculum.

Visually, it is possible to notice that the colonies of Control Group 3 (see Figure 2A) presented a slightly larger diameter compared to those of Experimental Group 3 (Figure 2 B) after 24 hours of incubation. The diameters of non-exposed colonies $(1.385 \pm 0.32 \mathrm{~mm})$ compared to those exposed $(1.107 \pm 0.39 \mathrm{~mm})$ showed a significant difference in size $(p=0.042)$, which would be an indication that the colonies of Experimental Group 3 (although numerous) were affected by the fluence used. However, upon being incubated for another 24 hours, the surviving colonies continued to proliferate. In Figure $2 \mathrm{C}$ and D, after 48 hours of incubation, the diameters of the colonies of Control Group $3(2.35 \pm 0.47 \mathrm{~mm})$ showed no significant difference in comparison with those of Experimental Group 3 (2.27 $\pm 0.49 \mathrm{~mm} ; \mathrm{p}=0.676)$.

\section{Discussion}

Photobiomodulation using blue light has been largely discussed as an alternative antimicrobial therapy. It shows positive results on in vitro experiments and demonstrates advantages as a treatment when compared with photodynamic therapy and ultraviolet light (Guffey and Wilborn, 2006; Enwemeka et al., 2008, 2009; Chui et al., 2012; De Lucca et al., 2012; Bumah et al., 2013, 2015; Dai et al., 2013; Kim et al., 2013; Pileggi et al., 2013; Sousa et al., 2015; Masson-Meyers et al., 2015; Rosa et al., 2016; Ferrer-Espada et al., 2019; Meurer et al., 2019; Rupel et al., 2019; Schmid et al., 2019). Nevertheless, the great variety of experimental protocols using blue light on bacterial inhibition creates difficulty to identify ideal light emission parameters to be adopted with confidence.

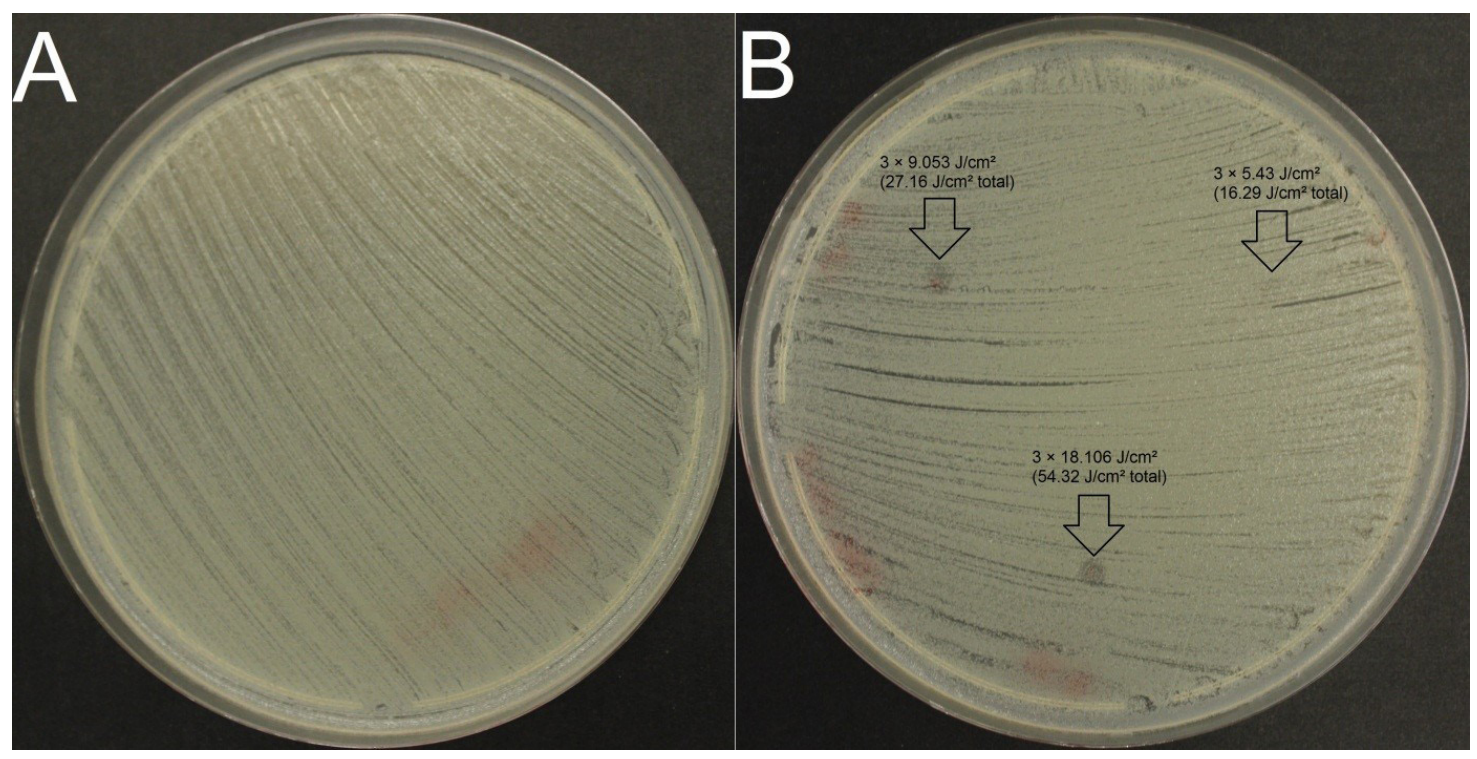

Figure 1. Agar plates representative of Experiment 1 (experimental group 2) showing S. aureus bacterial growth 24 hours after exposure to fractionated 16.29, 27.16 and $54.32 \mathrm{~J} / \mathrm{cm}^{2}$ fluences of blue light. (A) Control Group 2 not exposed to blue light; (B) Inhibition halos, indicated by arrows, on Experimental Group 2. Inhibition from fractionated $54.32 \mathrm{~J} / \mathrm{cm}^{2}$ fluence was the most effective. 


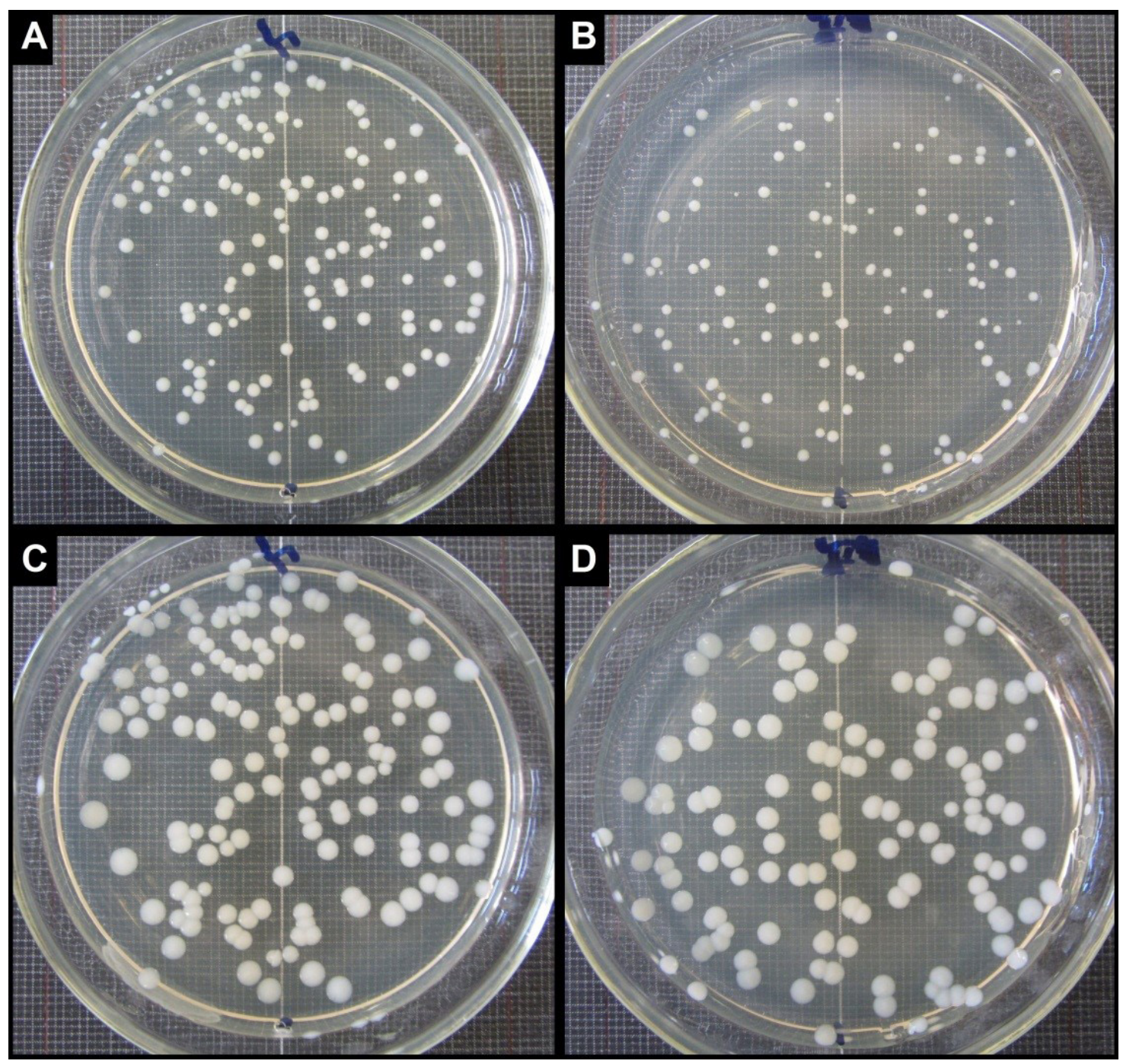

Figure 2. General appearance of the bacterial colonies grown on agar plates dishes of Experiment 2 after incubation for 24 and 48 hours. Cells were exposed to fractionated fluence of $54.32 \mathrm{~J} / \mathrm{cm}^{2}\left(3 \mathrm{X} 18.106 \mathrm{~J} / \mathrm{cm}^{2}\right)$. For both experimental and control group growth pattern occurred in a similar fashion, however cells exposed to blue light showed colonies with significantly smaller diameter. (A) Dish 1 of Control Group 3 after $24 \mathrm{~h}$ of incubation; (B) Dish 1 of Experimental Group 3 after 24 h of incubation; (C) Dish 1 of Control Group 3 after 48 h of incubation; (D) Dish 1 of Experimental Group 3 after $48 \mathrm{~h}$ of incubation.

Some investigations using blue light have reported $100 \%$ suppression of $S$. aureus proliferation on in vitro cultures (Guffey and Wilborn, 2006; Bumah et al., 2015). However, as shown in the present work, a great number of experiments described in the literature indicate only relative suppression of in vitro cultures when exposed to different patterns of the blue light emission (Enwemeka et al., 2009; Chebath-Taub et al., 2012; Chui et al., 2012; Dai et al., 2013; Guffey et al., 2013; Kim et al., 2013; Sousa et al., 2015; Masson-Meyers et al., 2015; Ferrer-Espada et al., 2019; Rupel et al., 2019; Schmid et al., 2019). This fact demonstrates the influence of the pattern of exposure and the need for better standardization of optimal parameters to obtain the best effect.
Some studies suggest that the bacterial inhibition action of blue light exposure is related to an increase of reactive oxygen species (ROS) that mediates harmful actions to the cell (Guffey and Wilborn, 2006; Enwemeka et al., 2008; Lipovsky et al., 2010; Dai et al., 2012; Chui et al., 2012; Kim et al., 2013; Bumah et al., 2015; Masson-Meyers et al., 2015; Rupel et al., 2019). Mouse and human cells exposed to blue light generates ROS production at levels that were not observed when the same type of cells was exposed to red or infrared light (Kushibiki et al., 2013). Some researchers indicate that even with high fluence values, the blue light does not harm DNA from mouse cells (Zhang et al., 2014; Rupel et al., 2019). However, other reports indicate that $410-420 \mathrm{~nm}$ wavelength emissions 
could cause cytotoxic fluence-dependent effects on human fibroblasts (Opländer et al., 2011).

Therefore, it is necessary to define emission parameters that inhibit $S$. aureus without bringing damage to human cells. The first parameter that needs attention is the wavelength. Different values starting from $405 \mathrm{~nm}$ have been used to verify the possible effect against $S$. aureus (Guffey and Wilborn, 2006; Lipovsky et al., 2010; Bumah et al., 2013, 2015). Values close to $470 \mathrm{~nm}$ are often chosen, showing good antimicrobial suppression results (Guffey and Wilborn, 2006; Enwemeka et al., 2009; Dai et al., 2012; De Lucca et al., 2012; Bumah et al., 2013, 2015; Pileggi et al., 2013; Sousa et al., 2015; Rosa et al., 2016; Cohen-Berneron et al., 2016; Ferrer-Espada et al., 2019; Meurer et al., 2019; Rupel et al., 2019; Schmid et al., 2019). Moreover, it has been shown that values between 453 and $480 \mathrm{~nm}$ are less cytotoxic to human cells (Opländer et al., 2011; Rupel et al., 2019). This suggests that values on this range (including the one used on the present paper) may be used as a pattern against $S$. aureus, due to its antimicrobial efficacy and greater safety level to host cells.

Irradiance represents the radiation flow per area unity received by a surface (Hadis et al., 2016), it is a variable parameter in different researches, although, in general, the values used are classified as photoemission of low intensity (Huang et al., 2011; Farivar et al., 2014). The protocols adopted in some investigations use 70 to 610 $\mathrm{mW} / \mathrm{cm}$ (Enwemeka et al., 2008; Lipovsky et al., 2010; Bumah et al., 2013; Sousa et al., 2015; Masson-Meyers et al., 2015; Rosa et al., 2016; Rupel et al., 2019), in other ones, values varies from 10 to $30 \mathrm{~mW} / \mathrm{cm}$ (Enwemeka et al., 2009; Bumah et al., 2013; Dai et al., 2013; Kim et al., 2013; Zhang et al., 2014; Schmid et al., 2019). However, it is difficult to establish a relation between low intensity irradiation values and bacterial inhibitory effect, because the results show similar inhibition levels. It is important to highlight that high irradiance patterns can extrapolate the limit of what is considered low intensity light irradiation (Farivar et al., 2014). On the other hand, when using very low values of this parameter, the light emission might last for too much time. The irradiances used in the present research $\left(19.92\right.$ and $\left.35.22 \mathrm{~mW} / \mathrm{cm}^{2}\right)$ showed results for in vitro experiments, although, it might not be the best option for in vivo experiments (considering the time spent), reinforcing that $\geq 70 \mathrm{~mW} / \mathrm{cm}^{2}$ may be the best interval for the irradiance choice.

Fluence is the energy delivered per cell area during a phototherapeutic emission (Hadis et al., 2016). This is an important parameter when studying blue light antimicrobial effects, also the one that presents the higher discrepancy on protocols used in different experiments. Some researchers state that only higher values (above $100 \mathrm{~J} / \mathrm{cm}^{2}$ ) are effective against $S$. aureus (Lipovsky et al., 2010; Chui et al., 2012; Ferrer-Espada et al., 2019); besides that, the supposed fluence-dependent inhibition effect cause controversial among scientific community (Guffey and Wilborn, 2006; Enwemeka et al., 2009; Lipovsky et al., 2010; Sousa et al., 2015; Rupel et al., 2019).
In this research, low fluencies were adopted: $16.29,27.26$ and $54.32 \mathrm{~J} / \mathrm{cm}^{2}$. When single exposure was used, no inhibition was noticed on irradiated cultures. In addition, it has been reported that low fluencies and the unique application of blue light have the potential to generate bacterial resistance (Guffey et al., 2013); thus, it is evident that this emission pattern is not desirable as an antibacterial method, representing a risk in hypothetical clinical use. However, when the exposure was fractionated in three applications, partial bacterial growth inhibition was verified. This result indicates that the fractionation of the blue light application optimizes its antimicrobial action on $S$. aureus. However, even when using fractional application, the use of low fluencies seems to be poorly recommended, as other authors have also been suggesting (Guffey et al., 2013; Rosa et al., 2016).

In the present study, the inhibition pattern found as a result of Experiment 1 indicates antibacterial effect on the superficial layers of the bacterial colony, however, it shows surviving bacteria proliferating in deeper layers of the colony.

In addition, Experiment 2 showed that there is no significant suppression of bacterial growth when $54.32 \mathrm{~J} / \mathrm{cm}^{2}$ fluence was used, even in fractionated application as measured by colony counts. Furthermore, at the end of the experiment the proliferation of all bacterial colonies has not been disrupted, which shows that low fluencies of blue light probably are not even capable of bacteriostatic action. The limited size of colonies grown upon exposure to blue light suggests an important influence on the metabolism and/or replication mechanism of this microorganism, but at the low fluencies used, this apparent harmful action was limited and the bacteria was able to circumvent this threat. This indicates that, regardless of the mechanism of action, the bacterial inhibition generated by the blue light becomes effective only at higher dosages, and it is important to verify if the proposed mechanism of action justifies this phenomenon. Thus, the best way to use the blue light against $S$. aureus could be the adoption of higher fluence values and the use of fractionated exposure of the light emission. A recently published paper has addressed the importance of the fluence and irradiance on blue light effectiveness using Pseudomonas aeruginosa as subject of the study and demonstrated similar observations as shown here (Rupel et al., 2019).

Therefore, it is important to continue address the issues discussed here and focus on the determination of safe parameters of blue light emission that can be used as a powerful bactericidal agent while not damaging host tissues. Once this is done, it will be possible to conduct in vivo experiments with greater precision, in order to better justify its use in human beings.

\section{Conclusion}

The present study showed that the use of low fluencies of blue light, provided by Light-Emitting Diodes, is not enough to generate satisfactory suppression in cultures of Staphylococcus aureus. Although the fluence of $54.32 \mathrm{~J} / \mathrm{cm}^{2}$ 
(fractionated in three applications) generated partial bacterial inhibition, the affected colonies were able to adapt and continue their proliferation. These results show the ineffectiveness of the use of low parameters values of blue light as an antimicrobial method since they promote only a reduction of bacterial growth and therefore would be of limited therapeutic potential.

\section{Acknowledgements}

We would like to thank CAPES - Coordenação de Aperfeiçoamento de Pessoal de Nível Superior, Brazil, for the fellowship awarded to I. D. C. Galo.

\section{References}

BUMAH, V.V., MASSON-MEYERS, D.S., CASHIN, S.E. and ENWEMEKA, C.S., 2013. Wavelength and bacterial density influence the bactericidal effect of blue light on Methicillinresistant Staphylococcus aureus (MRSA). Photomedicine and Laser Surgery, vol. 31, no. 11, pp. 547-553. http://dx.doi.org/10.1089/ pho.2012.3461. PMid:23621894.

BUMAH, V.V., MASSON-MEYERS, D.S., CASHIN, S. and ENWEMEKA, C.S., 2015. Optimization of the antimicrobial effect of blue light on Methicillin-resistant Staphylococcus aureus (MRSA) in vitro. Lasers in Surgery and Medicine, vol. 47, no. 3, pp. 266-272. http://dx.doi.org/10.1002/1sm.22327. PMid:25639752.

CHEBATH-TAUB, D., STEINBERG, D., FEATHERSTONE, J.D.B. and FEUERSTEIN, O., 2012. Influence of blue light on Streptococcus mutans re-organization in biofilm. Journal of Photochemistry and Photobiology. B, Biology, vol. 116, pp. 75-78. http://dx.doi.org/10.1016/j.jphotobiol.2012.08.004. PMid:22982208.

CHUI, C., HIRATSUKA, K., AOKI, A., TAKEUCHI, Y., ABIKO, Y. and IZUMI, Y., 2012. Blue LED inhibits the growth of Porphyromonas gingivalis by suppressing the expression of genes associated with DNA replication and cell division. Lasers in Surgery and Medicine, vol. 44, no. 10, pp. 856-864. http:// dx.doi.org/10.1002/1sm.22090. PMid:23129157.

COHEN-BERNERON, J., STEINBERG, D., FEATHERSTONE, J.D.B. and FEUERSTEIN, O., 2016. Sustained effects of blue light on Streptococcus mutans in regrown biofilm. Lasers in Medical Science, vol. 31, no. 3, pp. 445-452. http://dx.doi.org/10.1007/ s10103-016-1873-3. PMid:26796707.

DAI, T., GUPTA, A., HUANG, Y.Y., SHERWOOD, M.E., MURRAY, C.K., VRAHAS, M.S., KIELIAN, T. and HAMBLIN, M.R., 2013. Blue light eliminates community-acquired Methicillinresistant Staphylococcus aureus in infected mouse skin abrasions. Photomedicine and Laser Surgery, vol. 31, no. 11, pp. 531-538. http://dx.doi.org/10.1089/pho.2012.3365. PMid:23406384.

DAI, T., GUPTA, A., MURRAY, C.K., VRAHAS, M.S., TEGOS, G.P. and HAMBLIN, M.R., 2012. Blue light for infectious diseases: propionibacterium acnes, Helicobacter pylori, and beyond? Drug Resistance Updates, vol. 15, no. 4, pp. 223-236. http://dx.doi. org/10.1016/j.drup.2012.07.001. PMid:22846406.

DE LUCCA, A.J., CARTER-WIENTJES, C., WILLIAMS, K.A. and BHATNAGAR, D., 2012. Blue light (470 nm) effectively inhibits bacterial and fungal growth. Letters in Applied Microbiology, vol. 55, no. 6, pp. 460-466. http://dx.doi.org/10.1111/lam.12002. PMid:23009190.
ENWEMEKA, C.S., WILLIAMS, D., ENWEMEKA, S.K., HOLLOSI, S. and YENS, D., 2009. Blue 470-nm light kills Methicillin-resistant Staphylococcus aureus (MRSA) in vitro. Photomedicine and Laser Surgery, vol. 27, no. 2, pp. 221-226. http://dx.doi.org/10.1089/pho.2008.2413. PMid:19196103.

ENWEMEKA, C.S., WILLIAMS, D., HOLLOSI, S., YENS, D. and ENWEMEKA, S.K., 2008. Visible $405 \mathrm{~nm}$ SLD light photodestroys Methicilin-resistant Staphylococcus aureus (MRSA) in vitro. Lasers in Surgery and Medicine, vol. 40, no. 10, pp. 734-737. http://dx.doi.org/10.1002/lsm.20724. PMid:19065556.

FARIVAR, S., MALEKSHAHABI, T. and SHIARI, R., 2014. Biological effects of low level laser therapy. Journal of Lasers in Medical Sciences, vol. 5, no. 2, pp. 58-62. PMid:25653800.

FERRER-ESPADA, R., WANG, Y., GOH, X.S. and DAI, T., 2019. Antimicrobial blue light inactivation of microbial isolates in biofilms. Lasers in Surgery and Medicine, In press. http:// dx.doi.org/10.1002/lsm.23159. PMid:31536154.

FEUERSTEIN, O., 2012. Light therapy: complementary antibacterial treatment of oral biofilm. Advances in Dental Research, vol. 24, no. 2, pp. 103-107. http://dx.doi.org/10.1177/0022034512449469. PMid:22899690.

FREITAS, C.H., MENDES, J.F., VILLARREAL, P.V., SANTOS, P.R., GONÇALVES, C.L., GONZALES, H.L. and NASCENTE, P.S., 2018. Identification and antimicrobial suceptibility profile of bacteria causing bovine mastitis from dairy farms in Pelotas, Rio Grande do Sul. Brazilian Journal of Biology $=$ Revista Brasileira de Biologia, vol. 78, no. 4, pp. 661-666. http://dx.doi. org/10.1590/1519-6984.170727. PMid:29319754.

GUFFEY, J.S. and WILBORN, J., 2006. In vitro bactericidal effects of 405-nm and 470-nm blue light. Photomedicine and Laser Surgery, vol. 24, no. 6, pp. 684-688. http://dx.doi.org/10.1089/ pho.2006.24.684. PMid:17199466.

GUFFEY, J.S., PAYNE, W., JONES, T. and MARTIN, K., 2013. Evidence of resistance development by Staphylococcus aureus to an in vitro, multiple stage application of $405 \mathrm{~nm}$ light from a supraluminous diode array. Photomedicine and Laser Surgery, vol. 31, no. 4, pp. 179-182. http://dx.doi.org/10.1089/pho.2012.3450. PMid:23484587.

HADIS, M.A., ZAINAL, S.A., HOLDER, M.S., CARROLL, J.D., COOPER, P.R., MILWARD, M.R. and PALIN, W.M., 2016. The dark art of light measurement: accurate radiometry for low-level light therapy. Lasers in Medical Science, vol. 31, no. 4, pp. 789-809. http://dx.doi.org/10.1007/s10103-016-1914-y. PMid:26964800.

HUANG, Y.Y., SHARMA, S.K., CARROLL, J. and HAMBLIN, M.R., 2011. Biphasic dose response in low level light therapy - an update. Dose-Response, vol. 9, no. 4, pp. 602-618. http://dx.doi. org/10.2203/dose-response.11-009.Hamblin. PMid:22461763.

KIM, S.W., KIM, J.S., LIM, W.B., JEON, S.M., KIM, O.S., KOH, J.T., KIM, C.S., CHOI, H.R. and KIM, O.J., 2013. In vitro bactericidal effects of 625,525 , and $425 \mathrm{~nm}$ wavelength (red, green, and blue) light-emitting diode irradiation. Photomedicine and Laser Surgery, vol. 31, no. 11, pp. 554-562. http://dx.doi. org/10.1089/pho.2012.3343. PMid:24138193.

KUSHIBIKI, T., HIRASAWA, T., OKAWA, S. and ISHIHARA, M., 2013. Blue laser irradiation generates intracellular reactive oxygen species in various types of cells. Photomedicine and Laser Surgery, vol. 31, no. 3, pp. 95-104. http://dx.doi.org/10.1089/ pho.2012.3361. PMid:23390956. 
LIPOVSKY, A., NITZAN, Y., GEDANKEN, A. and LUBART, R., 2010. Visible light-induced killing of bacteria as a function of wavelength: implication for wound healing. Lasers in Surgery and Medicine, vol. 42, no. 6, pp. 467-472. http://dx.doi.org/10.1002/ 1sm.20948. PMid:20662022.

MASSON-MEYERS, D.S., BUMAH, V.V., BIENER, G., RAICU, V. and ENWEMEKA, C.S., 2015. The relative antimicrobial effect of blue $405 \mathrm{~nm}$ LED and blue $405 \mathrm{~nm}$ laser on methicillin-resistant Staphylococcus aureus in vitro. Lasers in Medical Science, vol. 30, no. 9, pp. 2265-2271. http://dx.doi.org/10.1007/s10103-0151799-1. PMid:26362142.

MEURER, L., PAYNE, W. and GUFFEY, J.S., 2019. Visible light as an inhibitor of Camplyobacter jejuni. International Journal of Antimicrobial Agents, vol. 55, no. 1, pp. 105818. PMid:31593764.

OPLÄNDER, C., HIDDING, S., WERNERS, F.B., BORN, M., PALLUA, N. and SUSCHEK, C.V., 2011. Effects of blue light irradiation on human dermal fibroblasts. Journal of Photochemistry and Photobiology. B, Biology, vol. 103, no. 2, pp. 118-125. http:// dx.doi.org/10.1016/j.jphotobiol.2011.02.018. PMid:21421326.

PILEGGI, G., WATAHA, J.C., GIRARD, M., GRAD, I., SCHRENZEL, J., LANGE, N. and BOUILLAGUET, S., 2013. Blue light-mediated inactivation of Enterococcus faecalis in vitro. Photodiagnosis and Photodynamic Therapy, vol. 10, no. 2, pp. 134-140. http://dx.doi.org/10.1016/j.pdpdt.2012.11.002. PMid:23769279.

ROSA, L.P., SILVA, F.C., VIANA, M.S. and MEIRA, G.A., 2016. In vitro effectiveness of 455-nm blue LED to reduce the load of Staphylococcus aureus and Candida albicans biofilms in compact bone tissue. Lasers in Medical Science, vol. 31, no. 1, pp. 27-32. http://dx.doi.org/10.1007/s10103-015-1826-2. PMid:26498601.
RUPEL, K., ZUPIN, L., OTTAVIANI, G., BERTANI, I., MARTINELLI, V., PORRELLI, D., VODRET, S., VUERICH, R., PASSOS DA SILVA, D., BUSSANI, R., CROVELLA, S., PARSEK, M., VENTURI, V., DI LENARDA, R., BIASOTTO, M. and ZACCHIGNA, S., 2019. Blue laser light inhibits biofilm formation in vitro and in vivo by inducing oxidative stress. Biofilms and Microbiomes, vol. 5, no. 29, pp. 1-11. http://dx.doi. org/10.1038/s41522-019-0102-9. PMid:31602310.

SCHMID, J., HOENES, K., VATTER, P. and HESSLING, M., 2019. Antimicrobial effect of visible light-photoinactivation of Legionella rubrilucens by irradiation at 450,470 , and $620 \mathrm{~nm}$. Antibiotics (Basel, Switzerland), vol. 8, no. 187, pp. pii:E187. http://dx.doi.org/10.3390/antibiotics8040187. PMid:31618994.

SOUSA, N.T.A., SANTOS, M.F., GOMES, R.C., BRANDINO, H.E., MARTINEZ, R. and GUIRRO, R.R.J., 2015. Blue laser inhibits bacterial growth of Staphylococcus aureus, Escherichia coli and Pseudomonas aeruginosa. Photomedicine and Laser Surgery, vol. 33, no. 5, pp. 278-282. http://dx.doi.org/10.1089/ pho.2014.3854. PMid:25954830.

WANG, Y., WANG, Y., WANG, Y., MURRAY, C.K., HAMBLIN, M.R., HOOPER, D.C. and DAI, T., 2017. Antimicrobial blue light inactivation of pathogenic microbes: state of the art. Drug Resistance Updates, vol. 33, no. 35, pp. 1-56. http://dx.doi. org/10.1016/j.drup.2017.10.002. PMid:29145971.

ZHANG, Y., ZHU, Y., GUPTA, A., HUANG, Y., MURRAY, C.K., VRAHAS, M.S., SHERWOOD, M.E., BAER, D.G., HAMBLIN, M.R. and DAI, T., 2014. Antimicrobial blue light therapy for multidrug-resistant Acinetobacter baumannii infection in a mouse burn model: implications for prophylaxis and treatment of combatrelated wound infections. The Journal of Infectious Diseases, vol. 209, no. 12, pp. 1963-1971. http://dx.doi.org/10.1093/infdis/ jit842. PMid:24381206. 